\title{
COMMENTS
}

\section{Employer Recognition of Unions on the Basis of Authorization Cards: The "Independent Knowledge" Standard}

In NLRB v. Gissel Packing Co., ${ }^{1}$ the United States Supreme Court confronted the question whether the National Labor Relations Board could order an employer to recognize a union as the representative of its employees solely on the basis of authorization cards rather than a certification election. In each of the four cases consolidated in the Gissel decision, the employer refused to bargain and committed substantial unfair labor practices ${ }^{2}$ after the union had demanded recognition with regard to a particular bargaining unit. The Board subsequently found that the employer had violated the duty to bargain imposed by section $8(a)(5)$ of the National Labor Relations Act $^{3}$ and issued a mandatory bargaining order.

On appeal, the Supreme Court upheld the Board's action. The Court noted that a Board-conducted election under section 9 (c) was the usual, but not the exclusive, method by which a union could demonstrate its majority support. Although prior Board decisions had broadly proclaimed, under the Joy Silk doctrine, ${ }^{4}$ that a bargaining order could issue

1395 U.S. 575 (1969). The decision represents the consolidation of four cases by the Supreme Court: Gissel Packing Co., Heck's Inc., and General Steel Products, Inc. from the United States Court of Appeals for the Fourth Circuit and Sinclair Co. from the United States Court of Appeals for the First Circuit.

229 U.S.C. § 158(a)(1) (1970) provides that it shall be an unfair labor practice for an employer "to interfere with, restrain, or coerce employees in the exercise of the rights guaranteed in Section 157 of this title." Id. § 158(a)(3) (1970) provides that it shall be an unfair labor practice for an employer "by discrimination in regard to hire or tenure of employment or any term or condition of employment to encourage or discourage membership in any labor organization ...."

$3 I d$. \& $158(\mathrm{a})(5)(1970)$ provides that it shall be an unfair labor practice for an employer "to refuse to bargain collectively with the representatives of his employees subject to the provisions of section 159(a) of this title."

4 Joy Silk Mills v. NLRB, 185 F.2d 732 (D.C. Cir. 1950), cert. denied, 341 U.S. 914 (1951). In this case, the United States Court of Appeals for the District of Columbia Circuit scrutinized the "totality of the evidence," including the commission of unfair labor practices and the time lapse between the refusal to bargain and the unlawful conduct, as the basis for a finding that the employer had acted in "bad faith" and thus had violated 
only if the employer had denied the union's majority status in "bad faith," the Court found it unnecessary to pass on the propriety of the subjective intent standard. ${ }^{5}$ Instead, it adopted the narrower rule, urged by the Board, that a bargaining order should issue where the union had obtained a majority of authorization cards and the employer's refusal to bargain was accompanied by independent unfair labor practices that tended to preclude the holding of a fair election. ${ }^{6}$

By limiting its decision to situations involving unfair labor practices, the Court left undetermined the appropriateness of a line of Board decisions finding section $8(a)(5)$ violations where the employer had "independent knowledge," apart from the authorization cards, that the union had a valid majority. ${ }^{7}$ In effect, the Board was permitted to consider further whether authorization cards are so inherently unreliable that unions should always be required to proceed to a certification election unless substantial unfair labor practices had occurred, ${ }^{8}$ or whether

section 8(a)(5). Although the court stated that the basic problem was whether the refusal to bargain had been motivated by bad faith, it recognized, in determining the intent of the employer, that neither the Board nor the courts "could read the minds of men." Whether the Board had issued a bargaining order based on the bad faith state-of-mind standard as measured by visible, wrongful acts, or whether the Board had based its bargaining order directly on the commission of such acts without reference to the employer's state of mind, appears unimportant as a practical matter. Even in cases such as Snow \& Sons, 134 N.L.R.B. 709 (1961), enforced, 308 F.2d 687 (9th Cir. 1962), in which no unfair labor practices were committed, there were still overt acts by the employer on which the Board grounded its bargaining order. Yet there has been much discussion about the logical faults of Joy silk because it purportedly sought to establish a standard of subjective intent. See Christensen \& Christensen, Gissel Packing and "Good Faith Doubt": The Gestalt of Required Recognition of Unions Under the NLRA, 37 U. CHI. L. Rev. 411 (1970); Lesnick, Establishment of Bargaining Rights Without an NLRB Election, 65 Mrck. L. REv. 851 (1967).

5395 U.S. at 601 n.18; see id. at 595.

B Gissel discussed three different contexts involving the commission of unfair labor practices. The first context involved an employer's commission of "outrageous' and "pervasive" " unfair labor practices that interfered with or were likely to interfere with the Board's election processes. In such cases, the Court intimated that the Board might issue a bargaining order without inquiring whether the union possessed a card majority. 395 U.S. at 613. This has been the holding of two cases since Gissel. J.P. Stevens \& Co., Gulistan Div. v. NLRB, 441 F.2d 514 (5th Cir. 1971); Bob White Target Co., 189 N.L.R.B. No. 128, 77 L.R.R.M. 1201 (197I). The second context involved an employer's commission of "less pervasive" unfair labor practices that were nevertheless found to have interfered with or to have threatened to interfere with the election processes. In this situation, the Court held that the Board could issue a bargaining order if it found that the union had a valid card majority at some point during the campaign. 395 U.S. at 614. The third context involved an employer's commission of unfair labor practices that were found to be "minor or less extensive" in terms of election interference. Such circumstances would not justify a bargaining order. Id. at 615 .

7 Id. at 593.

8 Brief for General Steel Products, Inc. at 23; Brief for Heck's, Inc. at 6. This proposition is vigorously asserted in NLRB v. S.S. Logan Packing Co., 386 F.2d 562, 565 (4th Cir. 1967): 
the existence of a card majority should be regarded as sufficient proof of union support to impose an obligation on the employer to bargain under section $8(\mathrm{a})(5) .^{9}$

This comment will examine the desirability of adopting the rule, proposed by the union in Gissel, that when presented with a card majority, an employer must within a reasonable time either recognize the union or petition for an election under section $9(\mathrm{c})(\mathrm{l})(\mathrm{B})$. The independent knowledge standard will be compared with this proposed rule to determine its effectiveness in resolving current card check problems.

\section{Authorization Gards as a Basis for Recognition: Background OF THE CONTROVERSY}

The language and legislative history of sections $9(\mathrm{a}), 9(\mathrm{c})(\mathrm{1})(\mathrm{B})$, and $8(a)(5)$ of the 1947 Taft-Hartley amendments to the Wagner Act suggest two contrasting conclusions concerning the legality of using authorization cards as a basis for recognition.10 Neither has been accepted by the Board or the federal courts.

One conclusion is that the Board should never issue a bargaining order without a Board-conducted election. Section $9(c)(1)(B)^{11}$ allows an employer to file an election petition whenever a union claims to represent his employees. It may thus be inferred that this right is not lost simply because the union's recognitional claim is based on authorization cards. In addition, the Senate Minority Report on the TaftHartley amendments ${ }^{12}$ stated, with some justification, that the effect of altering the similar Wagner Act provision ${ }^{13}$ was to make a certification election the only approved method for obtaining recognition. Yet the

"It would be difficult to imagine a more unreliable method of ascertaining the real wishes of employees than a 'card check', unless it were an employer's request for an open show of hands."

- Brief for Food Store Employees Local 347 at 19, 75.

10 Welles, The Obligation to Bargain on the Basis of a Card Majority, 3 GA. L. Rev. 349 (1969), contains a good discussion of the two contrasting conclusions to be drawn from the legislative history of these sections of the Act.

1129 U.S.C. $\S 159(\mathrm{C})(\mathrm{I})(\mathrm{B})(1970)$ provides for a possible hearing and an election whenever a petition shall have been filed, in accordance with such regulations as may be prescribed by the Board, "by an employer, alleging that one or more individuals or labor organizations have presented to him a claim to be recognized as the representative ...."

12 S. REP. No. 105, pt. 2, 80th Cong., 1st Sess. 34 (1947).

13 Law of July 5, 1935, ch. $372, \S 9$ (c), 49 Stat. 449 , provides: "Whenever a question affecting commerce arises concerning the representation of employees, the Board may investigate such controversy and certify to the parties, in writing, the name or names of the representatives that have been designated or selected .... In any such investigation, the Board ... may take a secret ballot of employees, or utilize any other suitable method to ascertin [sic] such representatives." The language with respect to "any other suitable method" of determining representatives was deleted from the Taft-Hartley provision. 
Board realized soon after the passage of the Taft-Hartley Act that a bargaining order was the most appropriate and adequate remedy when an employer's unfair labor practices had interfered with election processes $^{14}$ or when, apart from the commission of unfair labor practices, the employer had engaged in other types of conduct indicating that he did not have a good faith doubt as to the union's majority. ${ }^{15}$ The Board urged two reasons for ignoring the literal meaning of the Act. First, authorization cards provide a more reliable indication of employee sentiment when the employer's actions have made a fair election unlikely. Second, an employer should not be allowed to profit from his own wrongdoing by delaying the choice of a bargaining representative. ${ }^{16}$

An alternate conclusion that might be drawn from the legislative history is that an employer violates section $8(a)(5)^{17}$ whenever he refuses to bargain with a union presenting a card majority from an appropriate unit. Section 8(a)(5) defines an unfair labor practice to include the refusal to bargain collectively with the "representative" of the employees. Section $9(\mathrm{a}),{ }^{18}$ moreover, which provides for a certification election to establish the "representative" status of a petitioning party, does not specifically exclude the use of other methods. Indeed, the House version of section $8(a)(5),{ }^{19}$ which would have made a refusal to bargain an unfair labor practice only if the union were already certified under section 9 (a) or already recognized by the employer, was rejected by the Conference Committee in favor of the broader Senate version, which made it an unfair labor practice to refuse to bargain with the employees' "representative."20 One possible explanation for the rejection of the House version is that Congress, realizing that the Board had been granting recognition on the basis of authorization cards since the inception

If See note 4 supra.

15 E.g., Snow \& Sons, 134 N.L.R.B. 709 (1961), enforced, 308 F.2d 687 (9th Cir. 1962); F. \& W. Construction Co., 161 N.L.R.B. 852 (1966). In neither of these cases was there a finding of unfair labor practices on which a bargaining order could be grounded. In the former case, the employer reneged on an agreement to submit the authorization cards to an impartial third party for authentication. In the latter case, the employer stated wavering and inconsistent reasons for his refusal to recognize the union, evidencing the fact that he had no real doubt as to the union majority and that he was merely seeking delay. See also Jem Mfg., Inc., 156 N.L.R.B. 643 (1966); Dixon Ford Shoe Co., Inc., 150 N.L.R.B. 861 (1962); Kellogg Mills, I47 N.L.R.B. 342 (1964), enforced, 347 F.2d 219 (9th Cir. 1965).

16 Note, Union Authorization Cards, 75 YALE L.J. 805, 817 (1966).

1729 U.S.C. § 158(a)(5) (1970); see note 3 supra.

18 Id. § 159 (a) (1970).

10 H.R. 3020, 80th Cong., 1st Sess. $\S 8(a)(5)$, provides that it shall be an unfair labor practice for an employer "to refuse to bargain collectively with the representatives of his employees currently recognized by the employer or certified as such under section 9."

20 See note 3 supra. 
of the Wagner Act, intentionally refused to terminate this practice. Thus, it may be argued that authorization cards remain an alternative to a certification election and that an employer's refusal to accept such cards as proof of the union's majority status is equivalent to a refusal to bargain after a union has won a Board-conducted election.

Although the Taft-Hartley Act did not foreclose the use of authorization cards to establish union support, the Board has never held that presentation of cards from a majority of the members of the unit created an absolute duty to bargain. ${ }^{21}$ Since 1939 , the Board has made clear that authorization cards are not the functional equivalent of a certification election. ${ }^{22}$ Courts and commentators have offered three reasons for the Board's preference for certification elections. First, the opportunity for union organizers, including unit employees, to coerce an employee is much greater when an authorization card is used instead of secret ballot. ${ }^{23}$ Second, it is more likely that employees will misunderstand the import of signing an authorization card because of misreading, failure to read, or union misrepresentation. ${ }^{24}$ Third, the employer may have no opportunity to speak to his employees concerning their determination to have union representation, a right apparently guaranteed under section $8(\mathrm{c})$ of the Taft-Hartley Act, unless he is afforded the chance to make his views known during an election campaign. ${ }^{25}$

Any one of these three reasons would not alone justify a preference for a certification election over authorization cards. ${ }^{26}$ Together, they

21 Memorandum from Sec. of Labor Willard Wirtz to Sen. Jacob Javits, in Hearings on S. 256 Before the Senate Comm. on Labor and Public Welfare, 89th Cong., 1st Sess. 19, 20 (1965).

22* See Cudahy Packing Co., 13 N.L.R.B. 526 (1939).

23 Comment, Refusal-to-Recognize Charges Under Section 8(a)(5) of the NLRA: Card Checks and Employee Free Choice, 33 U. CHI. L. REv. 387, 390 (1966).

24 Note, supra note 16, at 823. But cf. Lesnick, supra note 4, at 864.

2529 U.S.C. $\$ 158$ (c) (1970) provides: "The expressing of any views, argument, or opinion, or dissemination thereof, whether in written, printed, graphic, or visual form, shall not constitute or be evidence of an unfair labor practice under any provisions of this subchapter, if such expression contains no threat of reprisal or force or promise of benefit."

26 The difficulty with accepting the first two rationales for preferring elections lies in the absence of empirical data. It may be just as reasonable to argue that unions can be as coercive in election campaigns as in card-signing campaigns and the employees as ignorant and misinformed in both campaigns. Bok, The Regulation of Campaign Tactics in Representation Elections Under the National Labor Relations Act, 78 HARv. L. REv. 38, 48-53 (1964), suggests that if political elections are any indication of the level of voter rationality and information existing in Board elections, election campaigns themselves rarely have influence in bringing about reasoned decisions by the voting electorate. See Goldberg \& Getman, Voting Behavior in NLRB Elections, in NEw YORK UNIVERSTTY TWENTYthird Annual Conference on Labor, Proceedings 115 (T. Christensen \& A. Christensen eds. 1971). The authors outline a study currently being conducted that is attempting to measure, among other things, the level of voter information and perception of employer and union 
have strongly influenced the development of the rules for recognition and explain in part the Court's reluctance in Gissel to expand its holding to encompass situations not involving unfair labor practices. The present rules for recognition, however, appear to fail in two respects. First, the independent knowledge test has proven unsatisfactory because of the subjective nature of the standard and the conflicting results that it has engendered. Second, the present rules foster delay. In particular, the current independent knowledge test allows the employer to force on the union a choice between either seeking a time-consuming Board determination of a section $8(a)(5)$ violation or petitioning on its own for a certification election. Because, as will be discussed later, a more protracted proceeding can and usually does result when a union petitions for a Board-conducted election than when an employer petitions for an election, this rule may promote employer delay and administrative inefficiency. ${ }^{27}$ It is to these two criticisms that we now turn.

\section{DeVELOPMENT OF THE "INDEPENDENT KNOWLEDGE" STANDARD}

The "independent knowledge" doctrine states that an employer who refuses a union request for recognition based on an authorization card majority may be subject to a mandatory bargaining order if he had knowledge, independent of the cards, that the union possessed the support of a majority of the members of a unit. ${ }^{28}$ The rule, developed in a series of Board decisions beginning with Snow b Sons, has practical significance in situations in which the employer has not committed a substantial unfair labor practice. In general, the rule has proven difficult to apply because of the subjective nature of the inquiry.

activity in Board elections. The third rationale is suggested by the wording of the statute. See note 25 supra. The courts have protected the employer's right to influence the vote of his employees through noncoercive speech. NLRB v. Gissel Packing Co., 895 U.S. 575 (1969); Thomas v. Collins, 323 U.S. 516, 537-38 (1945); NLRB v. Virginia Elec. \& Power Co., 314 U.S. 469 (1941); Suprenant Mfg. Co. v. NLRB, 341 F.2d 756 (6th Cir. 1965). It may be argued, of course, that section $8(c)$ does not guarantee the employer a right to express his views during an election campaign, but rather merely states that noncoercive speech may not be evidence of an unfair labor practice. Yet the spirit of the statute suggests that not only does the employer have an interest in speaking to his employees under the protection of section $8(\mathrm{c})$, but also that his employees have an interest in hearing his side. The guarantee of employer noncoercive free speech is also grounded on principles of fairness. In the card check context, for example, it is often said that employers are surprised in learning that the union has obtained a card majority from employees. Yet in Gissel and Heck's, Inc., both employers knew of the union's organization campaign from its inception. See also NLRB v. Gissel Packing Co., 395 U.S. 575, 603 (1969): "Normally, however, the union will inform the employer of its organization drive early in order to subject the employer to the unfair labor practice provisions of the Act."

27 See note 48 infra.

28 NLRB v. Gissel Packing Co., 395 U.S. 575, 592-93 (1969). 
In Snow \& Sons, ${ }^{29}$ the employer, upon being presented with an apparent card majority, at first refused to recognize the union and insisted that it petition for an election. Subsequently, he agreed to submit the cards to an impartial third party for a determination of their authenticity. After authentication by the third party, however, the employer refused to recognize the union, declaring that he never considered the agreement binding on him. The Board ruled that where an employer had agreed to submit union authorization cards to an impartial third party for verification and the cards had been so authenticated, a subsequent refusal to bargain would be deemed not to have been based on a reasonable doubt as to the union's majority. The authentication in question was regarded as having provided the employer with "independent knowledge." 30 The crucial factor, the prior agreement by the employer to submit to the procedure, was to figure predominantly in later Board decisions.

The principle that objective facts other than unfair labor practices could support the issuance of a mandatory bargaining order, even where the employer had simply refused to submit the cards to an impartial third party, was subsequently endorsed in Bernel Foam Products. ${ }^{31}$ The Board broadly interpreted Snow of Sons as holding that an employer violates section $8(a)(5)$ where he entertains no reasonable doubt with respect to either the proposed unit or the union's representative status and seeks a Board-directed election without a valid ground.32 That Bernel Foam also involved substantial employer unfair labor practices, however, raises some doubt whether it can be read as extending Snow \& Sons by including within the independent knowledge category those cases in which the employer simply rejects an offer of impartial card verification.

Until 1970, the Board apparently applied the Snow of Sons doctrine only where an employer had reneged on an agreement to have the cards authenticated by an impartial party and to be bound by such authentication. ${ }^{33}$ Following Gissel, however, two Board decisions abandoned

29134 N.L.R.B. 709 (1961), enforced, 308 F.2d 687 (9th Cir. 1962).

30 Although not mentioned in Snow \& Sons, the term "independent knowledge" was in common use by the time Gissel was decided. Snow of Sons is usually cited as the first case to deal with the independent knowledge notion.

31146 N.L.R.B. 1277 (1964).

32 Id. at 1283.

33 Lesnick, supra note 4, at 852. John P. Serpa, Inc., 155 N.L.R.B. 99 (1965), was considered to be a severe limitation of Snow \& Sons. Dealing with a factual setting virtually identical with that in Snow of Sons, the Board dismissed an unfair labor practice complaint and refused to issue a bargaining order on the ground that the employer's agreement concerned his own inspection of the cards, and not an inspection by an impartial third party. The court of appeals reversed, holding that the employer had been motivated by bad faith. 376 F.2d 186 (9th Cir. 1967). 
the prior agreement requirement. In Pacific Abrasive, ${ }^{34}$ presentation of the card majority was accompanied by the employer's verification of the signatures on the cards, his acknowledgment of their authenticity, his conversations with employees that brought forth their support of the union, and a strike by a majority of the unit in support of the recognitional request. The Board concluded that these facts convincingly indicated the requisite independent knowledge and invoked United Mine Workers v. Arkansas Oak Flooring Co.$^{35}$ to support its finding that the denial of recognition violated section $8(a)(5)$. In effect, the Board found that under the facts of the case, the employer must have known that the union had a majority even though there had been no agreement to have the cards authenticated. The Board explicated by including a relevant quotation from Gissel:

When confronted by a recognition demand based on possession of cards allegedly signed by a majority of his employees, an employer need not grant recognition immediately, but may, unless he has knowledge independently of the cards that the union has a majority, decline the union's request and insist on an election, either by requesting the union to file an election petition or by filing such a petition himself under section $9(\mathrm{c})(\mathrm{l})(\mathrm{B}){ }^{36}$

The Board's subsequent decision in Wilder Manufacturing Co. ${ }^{37}$ involved a situation in which the employer had independent knowledge of the union's majority, but did not file an election petition himself or suggest that the union do so. The Board found a violation of section $8(a)(5)$ and issued a bargaining order. As in Pacific Abrasive, the requirement of independent knowledge was satisfied by the presentation of a card majority, the employer's acknowledgment in discussions with his fellow company officers that the union appeared to have a majority, and the participation of a unit majority in a picket line and a strike in support of the recognition demand. The employer's discussions with employees, which had constituted evidence of independent knowledge in Pacific Abrasive, were absent from the facts of the case.

After Wilder, it seemed that the employer's mere verbal acknowledgment of the union's card majority might constitute evidence of independent knowledge. In addition, the Board made it possible for

34182 N.L.R.B. No. 48, 74 L.R.R.M. 1113 (1970).

35351 U.S. 62 (1956). The holding of this case did not concern the employer's obligation to bargain absent his commission of unfair labor practices. Rather, it concerned the right of a state court to enjoin a recognitional picket by a unit majority after the submission of that majority's authorization cards to the employer. The importance of the citation in Pacific Abrasive was the very broad language utilized by the Board to justify issuance of a bargaining order.

30182 N.L.R.B. No. 48, 74 L.R.R.M. at 1115 (emphasis in original).

37185 N.L.R.B. No. 76, 75 L.R.R.M. 1023 (1970). 
unions with card majorities to create evidence of independent knowledge by engaging in a strike or picketing. ${ }^{38}$ In such a situation, the employer's only alternative to an eventual bargaining order was to insist upon an election. The Board in Wilder did not require, however, that the employer petition for an election under section $9(\mathrm{c})(1)(\mathrm{B})$, but rather suggested that he might alternatively request the union do so. This requirement, not suggested in Pacific Abrasive, that the employer indicate the possibility of an election to the union, rather than remain silent, is somewhat perplexing. It appears to rest on the unwarranted assumption either that employers are more informed than unions about the right to a Board-conducted election or that the employer's act constitutes a demonstration of good faith.

Although the Board's extension of the concept of independent knowledge beyond the narrow holding of Snow of Sons permitted more flexible handling of the card check situation, it seemed inappropriate that the issuance of a bargaining order should turn on whether the employer had inadvertently admitted that the union appeared to have a majority. Furthermore, it was incongruous that the Board should encourage recognitional striking and picketing by regarding them as an independent, affirmative method of demonstrating a majority, particularly since some workers might honor a picket line without necessarily supporting the union.

Realizing that it had defined the independent knowledge requirement too broadly, the Board began to retreat toward the narrow holding of Snow \& Sons. In Redmond Plastics, ${ }^{39}$ the Board found that the employer's initial acknowledgment to union officers that they appeared to have a union majority, together with a tentative agreement to talk with the union conditioned on the employer's opportunity to discuss the matter with his lawyer beforehand, justified the issuance of a bargaining order. The decision identified the "prior agreement" element as the critical factor, citing Snow \& Sons as authority. Chairman Miller's vigorous dissent in Redmond noted that the employer's agreement to talk with union officials did not constitute the kind of agreement on which the ruling in Snow \& Sons was predicated. In Snow \& Sons, the employer had agreed to submit the authorization cards to an impartial third party for authentication. In Redmond, the employer acknowledged that the cards were authentic, and the real issue was whether the employer had made a firm promise to bargain with the union. The

$38 I d ., 75$ L.R.R.M. at 1024. In this respect, it is instructive to note that in Gissel, the Supreme Court recognized the possibility of an affirmative showing of majority support by a strike or a strike vote. 395 U.S. at 597 .

39187 N.L.R.B. No. 60, 76 L.R.R.M. 1035 (1970). 
majority might have blunted Miller's criticism had it unequivocally admitted that this agreement was different in character from that in Snow \& Sons and proceeded to base its bargaining order on the broader ground that the need to prevent employer delaying tactics, which was the underlying justification for Snow \& Sons, was the critical factor in the present case. Instead, the Board declared that Snow \& Sons was directly applicable.

The Board's later decision in Summer \& Co.40 represents the abandonment of the Wilder position and the reinstatement of the narrower Snow \& Sons rule. In Summer \& Co., the employer at a prehearing conference $^{41}$ attempted to introduce facts regarding the solicitation of employees by supervisors, but was rebuffed by the hearing officer, who correctly pointed out that such issues were not litigated at these conferences. The employer responded that he would not bargain with the union even if a Board-conducted election were held. After the union withdrew its petition for an election, the employer told the union that if it submitted a new petition, supported by a "fresh" thirty percent showing of support through authorization cards, the company would agree to a consent election. When the union responded that it had the support, the employer claimed that those signing the cards had been organized by supervisors and that there was no "fresh" showing. Subsequently, a majority of the employees struck in support of the recognition demand.

The Board found that although the employer had violated section $8(a)(3), 42$ the violation was insufficient to support a bargaining order under Board standards laid down after Gissel. The Board then declared that absent the commission of unfair labor practices, there was no method by which it could discern bad faith on the employer's part unless, as in Snow \& Sons, he had reneged on a prior agreement to submit the cards to an impartial third party. The Board made a weak attempt to distinguish Wilder by asserting that it concerned not only independent knowledge, as did the present case, but also the employer's unwillingness to resolve any lingering doubts through a certification election. Contrary to the Board's assertion, however, the language of Wilder would seem to apply since the employer in Summer \& Co. had stated at the prehearing conference that he would not abide by the results of an election. Despite his subsequent letter to the union suggest-

40190 N.L.R.B. No. 116, 77 L.R.R.M. 1305 (1971).

$\$ 129$ C.F.R. § 102.63(b) (1971) and id. § 102.62(b) (1971) can be read as authorizing such prehearing conferences, particularly for the purpose of deciding whether a consent election is possible.

4229 U.S.C. \$ 158(a)(3) (1970); see note 2 supra. 
ing a Board-conducted election, the employer's statement certainly left grave doubts as to his willingness to resolve his doubts about the union's majority through the election process. Furthermore, even if the majority's reasoning distinguished Wilder, it did not dispose of Pacific Abrasive, in which the Board had not made employer insistence upon an election a factor to be considered in the independent knowledge context. ${ }^{43}$

The majority's disingenuous distinction was roundly criticized by members Fanning and Brown, who had joined in the majority decision in Wilder. They flatly declared that Wilder was significant because it did not turn on the element of prior agreement and that by returning to this requirement, the Board had overruled Wilder sub silentio. The majority did admit that it was reassessing the wisdom of attempting to divine, in retrospect, the state of the employer's knowledge or intent at the time he denied a union demand for recognition. ${ }^{44}$ Although the Board did not discuss it, it seems that the real issue was whether the Board could ever define coherent and administratively feasible objective criteria for ascertaining the existence of independent knowledge.

The difficulty with the independent knowledge standard has been the Board's use of it to arrive at two qualitatively different conclusions. Where the employer has agreed to resolve his doubts regarding the union's majority outside the Board's election process, as in Snow \& Sons and Redmond Plastics, the Board's refusal to allow him to renege on the agreement is presumably intended to encourage administrative efficiency and to prevent employer delay. ${ }^{45}$ In contrast, where a unit majority has struck or the employer has admitted that the union appears to have a majority, ${ }^{46}$ the Board's decision whether to issue a bargaining order is based on a determination of the employer's state of mind, in which the primary concern is his bad faith.

Because the independent knowledge standard is misleading when one considers cases such as Snow \& Sons, it should be eliminated. Instead, the Board should approach these cases in terms of what types of

43 1970-1971 Annual Survey of Labor Relations Law, 12 B.C. IND. \& CoM. L. REv. 1026, 1058 (1971), suggests that unit size may be the factor that distinguishes Pacific Abrasive from Wilder. Thus, when the unit is large, as in Wilder, the employer has an obligation to insist on an election. An alternate and more persuasive interpretation is that in Wilder, the Board was adding a gloss to the rule established in Pacific Abrasive. Summer \& Co. is therefore a rejection of Pacific Abrasive as well as Wilder.

44190 N.L.R.B. No. 116, 77 L.R.R.M. at 1309. This opinion may also portend a change in the Board's attitude toward cases such as H. \& W. Construction Co., 161 N.L.R.B. 852 (1966).

45 Cf. Retail Clerks Local 1179 v. NLRB, 376 F.2d 186 (9th Cir. 1967).

46 See note 38 supra. 
employer conduct, apart from the commission of unfair labor practices, will be prohibited in the authorization card context. As the Board correctly argued in Gissel, determination of an employer's subjective intent is often impossible. The independent knowledge standard should not be a vehicle for a return to Joy Silk.

\section{Recognition on the Basts of Authorization Cards:}

\section{A Proposed Rule}

Complete abandonment of the current independent knowledge standard would permit the Board to establish a more consistent and coherent test governing the recognition context. One suggested rule ${ }^{47}$ is that an employer, when presented with an authorization card majority, must either recognize the union or within a reasonable time petition for a certification election. The proposed rule, which could be adopted under the Board's rule-making power, would cure several defects, including the potential for delay, that exist in current Board procedures for handling authorization card situations.

The proposed rule would result in a speedier election process because it would help obviate employer use of delaying tactics. ${ }^{48}$ The current independent knowledge standard creates an incentive for the employer not to recognize the union, but rather to petition for and prolong a preelection hearing or to withhold recognition until the union is forced to initiate a lengthy section $8(a)(5)$ proceeding. By making independent knowledge irrelevant, the rule would decrease the possibility that the

47 NLRB v. Gissel Packing Co., 395 U.S. 594, 594-95 (1969).

48 In 1970, in contested elections, in which at least one party has moved for a preelection hearing, the median time between the filing of an election petition and the regional director's decision to proceed to an election was forty-three days. This figure has remained fairly constant since 1962. 35 NLRB ANN. REP. 12 (1970). In consent elections, in contrast, in which the preelection hearing is waived, the usual time between the filing of the petition and the agreement to proceed to an election is three to five days. The usual time between the agreement to proceed to an election and the holding of the election is seventeen to twenty days. Interview with Martin Schneid, Assistant to the Regional Director, NLRB, in Chicago, III., Feb. 3, 1972. It may generally be assumed that the period between either the regional director's order of an election or the parties' agreement to an election, on the one hand, and the holding of the election, on the other, will be the same in both cases, that is, seventeen to twenty days. Thus, an election contested through submission of objections at a preelection hearing is likely to take sixty to sixty-three days between petition and balloting, while a consent election, in which the hearing is waived, is likely to take only twenty to twenty-three days. Certainly, a delay of roughly forty days could have great significance where the union has a tenuous majority, the union's enthusiasm has peaked at the time of the recognitional request, or there is a large, amorphous unit and the employer is sophisticated in the methods of dealing with union organizers. On this last point, see Fogel, The Teamsters and NLRB Representation Elections, 1962-63, 15 LAB. L.J. 649 (1964). 
employer would succeed in the section $8(a)(5)$ proceeding. The only issues in such a proceeding would be whether there was a valid card majority and an appropriate unit. Thus, the employer would be more likely to petition for an election. ${ }^{49}$ The proposed rule would also, however, reduce the potential for delay that currently exists in the election process. Under Board rules, when a petition for an election has been filed, the regional director may, at his discretion, convene a preelection hearing if a proper party questions the propriety of the petition. ${ }^{50}$ Where the union requests an election, an employer desiring to delay as well as contest the election may obtain a hearing by challenging, in various ways, the appropriateness of the bargaining unit as well as the validity of the card majority. Customarily, the regional director grants a hearing upon request.51 It appears that skillful counsel can prolong the hearing for a considerable period of time, as a means of delaying the election, by raising many frivolous as well as serious objections to the cards and the unit. ${ }^{52}$ If, however, the employer were to petition for an election, he would be required to define the appropriate unit and therefore would not be entitled, as an objecting party, to request a hearing. ${ }^{58}$ Where the employer petitioned for an election, the union, in effect, would be afforded the opportunity to waive the hearing by not raising objections that would result in delay.

Conceivably, a union would be willing to forego a preelection hearing to challenge the appropriateness of the unit suggested by the employer for several reasons. First, enthusiasm for the union might have peaked when the card majority was obtained and the request for recognition was made. Delay caused by a long hearing could result in the dis-

49 It might be argued that such a rule would increase the number of frivolous employer petitions prompted by frequent union requests for recognition as a means of harassment. The statutory bar of section 9(c)(3), which allows elections in a given unit only once a year, will act as a deterrent to future harassment where there has been a showing of substantial support and an election is held. 29 U.S.C. \$ 159(c)(3) (1970). If the employer believes the union is harassing him, yet does not have a majority, he can refuse the request and force the union to initiate a section 8(a)(5) proceeding. As a means of preventing harassment, the Board might couple the granting of a dismissal of the employer petition with an order forbidding the union involved from organizing within the unit for a period of time where there was no dispute as to the appropriate unit.

5029 C.F.R. § 102.63(b) (1971). The preelection hearing, at which issues such as the appropriateness of the unit are resolved, should not be confused with the prehearing conference, at which, among other things, the possibility of holding a consent election is discussed.

51 Interview with Martin Schneid, supra note 48.

52 Interview with Albert Gore, Counsel for Food Store Employees Local 347 in Gissel, in Chicago, I11., Feb. 1, 1972; Interview with Martin Schneid, supra note 48.

53 Under 29 C.F.R. $\S 102.60$ (1971) and id. $\S 102.63(\mathrm{~b})$ (1971), it is customary for interested parties other than the moving party to file for clarification of the bargaining unit or for a hearing regarding the appropriateness of the suggested unit. 
sipation of its majority status. Second, the union might decide to accept a smaller employer-suggested unit in order to establish a "beachhead" from which it could further organize, rather than risk losing the election because of delay. Such a waiver would be less likely to occur under current Board procedures because a union, as a petitioning party, is obligated to defend its suggested unit vigorously in order to maintain the loyalty of its members and to increase its prospects for broader support. This tendency is reinforced by the fact that the hearing is a public proceeding and may be attended by members of the suggested unit. ${ }^{54}$ Third, even if the employer proposed frivolous or ridiculous units to foster delay, the regional director could summarily dispose of these suggestions at the "investigation" stage in considering the employer petition; no hearing would be necessary. ${ }^{55}$ Furthermore, in those situations in which it felt compelled to request a hearing, as when unit determination involved complicated issues, the union might shorten the proceeding considerably by limiting the number and scope of the challenges to the appropriateness of the unit. The usual employer technique for lengthening delay is to object to as many alleged unit members as possible on any and all conceivable grounds.

In any event, if the employer-proposed unit were unacceptable to the union, it could obtain dismissal of the employer's petition without penalty by disclaiming interest in the unit, provided that the unit proposed by the employer differed substantially from the unit proposed through authorization cards. ${ }^{58}$ Only where the Board found, at the investigation stage, that the employer-proposed unit was not frivolous and where the union could neither realistically accept the unit nor limit its challenges to any significant degree would the preelection hearing be as long as those currently conducted.

Certainly, employers who desired to avoid an immediate election could react to the proposed rule by attempting to find other avenues for delay. The most obvious method would be to procrastinate in filing the petition. The Board could resolve this problem, however, by defining what constitutes a "reasonable time" within which the employer must request an election. Adoption of a rule similar to that of Excelsior Underwear, Inc., ${ }^{57}$ by which a fixed period of time could be specified

54 Undex 29 G.F.R. § 102.64(a) (1971), the preelection hearing must be open to the public.

55 Under 29 C.F.R. $\$ 102.63$ (1971), the regional director undertakes an investigation prior to any hearing to determine if there is a "reasonable cause to believe a question of representation ... exists." At this stage, the Board itself may request that the employer suggest a more appropriate bargaining unit.

68 This remedy is available under current Board Procedures. See note 49 supra.

87 Excelsior Underwear, Inc., 156 N.L.R.B. 1236 (1966). The Board ruled that the failure to furnish to the union a list of eligible voters within the unit constituted grounds for setting aside the election. After the approval by the director of a consent election 
for the employer's response, would minimize this means of delay. More difficult would be the problem of dealing with an employer who continued to propose inappropriate units despite the regional director's dismissal of each previous unit. Although the union's decision to waive its objection by accepting the inappropriate unit or to request a hearing based only on the exclusion of certain key employees could eliminate the problem, a bargaining order would appear to be the most effective response to blatantly obstructive conduct. Of course, this approach might be criticized as an attempt to reintroduce the very element that the rule purports to expunge from Board considerations in the card check context, that is, a subjective intent standard. It seems plausible, however, that the criteria for determining whether a party is abusing Board procedures might be more easily developed and more consistently applied than were the criteria for independent knowledge simply because the inquiry would be directed at the narrow question whether the employer has in fact delayed the election process unjustifiably. Furthermore, the benefits to be gained from the significant decrease in time between petition and election far outweigh the difficulties of employing such a test.

By requiring employers either to recognize the union or to petition for an election, the Board would be separating those employers having legitimate doubts concerning the representative status of the union from those seeking to delay recognition by means that do not subject them to the risk of a bargaining order. The alternate route, the skillfully delayed preelection hearing, would be closed.

This rule would actually increase the employer's rights because he could still petition for a Board-conducted election even though he had independent knowledge of the union's majority. The only exception would be in those instances in which the employer had committed substantial unfair labor practices that made holding a fair election impractical. Of course, if the employer wanted to contest the validity of the cards and had not committed substantial unfair labor practices, he could raise the issue in a section $8(a)(5)$ proceeding. Even if this situation were to arise, the obligation to recognize the union would be easier for the Board to determine. If presented with a charge by the union that the employer had violated section $8(a)(5)$ by refusing to recognize

agreement or after the direction of an election, the regional director requests the employer to prepare and submit a list of the names and addresses of the unit's eligible voters within seven days of such approval or direction. NLRB FIELD MANUAL § 11312.1 (1970). Because of the differing sizes of units and complexities of unit determination, a fixed time period for employer petitions must represent an outer limit within which an employer could satisfy his obligation. If the employer were considering the possibility of challenging the union's claim of a majority in a section 8(a)(5) proceeding, he could conduct a poll of his employees during this period. See Struknes Constr. Co., 165 N.L.R.B. 1062 (1967). 
the union or petition for an election, the Board would not have to inquire into independent knowledge of the existence of a prior agreement. If the Board found that a valid card majority existed within an appropriate unit, then the employer's action would constitute a section 8 (a)(5) violation, and a bargaining order would result. The last vestiges of Board inquiry into the employer's state of mind with respect to the validity of a card majority would be eliminated. The employer's good faith would not be determinative of the obligation to recognize.

Finally, there would be adequate assurance that the employees would have had an opportunity to express their choice of representatives even if a bargaining order issued without an election because in a section $8(a)(5)$ proceeding, the Board would be required to find an uncoerced, valid card majority within an appropriate unit before issuing such an order.

The effectiveness of the proposed rule, as well as current Board procedures, would be further improved by broadening the range of the Board's remedies for the flagrant abuse of section 8(a)(5) proceedings. In International Union of Electrical Workers $v . N L R B,{ }^{58}$ Judge Leventhal suggested that it would not be beyond the Board's power under the NLRA to award damages to the union on the basis of what the parties might have agreed to had the employer bargained rather than flagrantly misused the section $8(a)(5)$ proceeding. Although declining to adopt this "make-whole" remedy on remand, the Board did award certain costs to the union because of the flagrant abuse of the proceeding. ${ }^{59}$ Such a remedy would no doubt be useful in deterring an employer from delaying the section $8(a)(5)$ proceedings by proposing inappropriate units as a means of delay. If the potential for delay were reduced, the employer would be more likely to petition for an election to resolve his doubts about the union's majority. Absent stringent penalties for its misuse, the section $8(a)(5)$ proceeding would remain an attractive alternative to employers regardless whether the union or the employer were required to petition. ${ }^{60}$ Nevertheless, the possibility of a lengthy section $8(\mathrm{a})(5)$ proceeding does not vitiate the advantages of

58426 F.2d 1243 (D.C. Cir. 1970).

59 Tiidee Products, Inc., 194 N.L.R.B. No. 198, 79 L.R.R.M. 1175 (1972).

60 NLRB v. Gissel Packing Co., 395 U.S. 575, 611 n.30 (1969), indicates that in 1968, the median time between the filing of an unfair labor practice charge and a Board decision in the matter was 388 days. This figure would presumably be larger if there were added the mean time necessary to obtain enforcement orders from the courts of appeals. Compare the figures for the length of section 8(a)(5) with the figures for the length of certification elections in note 49 supra. The comparison makes it obvious that a truly belligerent employer might find it worth his while to refuse recognition of a union and to engage in unfair labor practices that would irreparably impair the election processes. See Bok, supra note 26, at 59 n.46. 
adopting the general rule that in the card check situation, the employer must either recognize the union or petition for an election.

\section{Conclusion}

The question whether a bargaining order may be issued in a card check situation absent commission by the employer of unfair labor practices was avoided by the Supreme Court in Gissel and has since been dealt with inconsistently by the NLRB. Sound policy reasons suggest that the Board and courts should abandon the independent knowledge standard. A more beneficial approach would involve the adoption of a broader rule requiring the employer, when presented with an authorization card majority, either to recognize the union or to petition for a certification election under section $9(c)(1)(B)$ of the NLRA. Employer refusal to bargain with the union or to petition for an election within a reasonable period of time would be grounds for the issuance of a bargaining order for violation of section $8(a)(5)$.

Charles B. Burch 